\title{
Experimental study on thiosulfate leaching of gold from a high copper gold concentrate
}

\author{
CHEN Yanbo ${ }^{1, *}$, QIN Guanglin ${ }^{1}$, LI Guangsheng ${ }^{1}$, ZHU Xingfu ${ }^{1}$, YU Congquan ${ }^{1}$, LU Zhongbo ${ }^{1}$, JI Qiang ${ }^{1}$, ZHANG \\ Juntong $^{1}, \mathrm{XU}^{\mathrm{C}} \mathrm{Chao}^{1}$, CAI Mingming ${ }^{1}$, GAO Tengyue ${ }^{1}$
}

${ }^{1}$ Selection and metallurgy laboratory of Shandong Gold Mining Technology Co.Ltd.,Yantai,Shandong, 261441

\begin{abstract}
The conventional cyanide leaching process is used to extract gold from a high copper gold concentrate. Because the copper associated minerals consume sodium cyanide in large quantities, the cost of the reagents is high and the economic benefit is not ideal. At the same time, a large number of cyanide tail slag are produced, which brings a series of environmental problems. In order to solve the environmental problems caused by excessive sodium cyanide consumption and cyanogen slag, the feasibility of leaching gold by thiosulfate in copper ammonia system was studied. The gold leaching rate of thiosulfate was increased to more than $90 \%$ by using the direct thiosulfate leaching process and pretreatment thiosulfate leaching process, which was close to the gold leaching index of sodium cyanide at the production site.
\end{abstract}

\section{Introduction}

Cyanidation is widely used in gold dressing and metallurgy because of its simple operation and high recovery. However, cyanide is highly toxic, and the cyanide residue is hazardous waste, which is difficult to transport and seriously pollutes the environment ${ }^{[1]}$. In recent years, a large number of non cyanide gold extraction technologies such as thiourea process, thiosulfate process, halogen process, polysulfide process and stone sulfur mixture process have been reported. Among them, thiosulfate method has the advantages of fast gold leaching speed, non-toxic, insensitive to impurities and no corrosion to equipment ${ }^{[2]}$. Especially for refractory gold ores containing as, $\mathrm{Cu}$ and carbon, the recovery effect of gold is obviously better than that of cyanide $^{[3]}$. The conventional cyanidation leaching process was used to extract gold from a high copper gold concentrate, resulting in a large amount of cyanidation tailings, which caused serious environmental problems. And because the copper content is more than $3 \%$, a large amount of cyanide is consumed in the process of cyanide leaching, resulting in high cost of reagent and poor economic benefit. Therefore, based on the analysis of the properties of the ore, the feasibility of leaching gold with thiosulfate in copper ammonia system was explored.

\section{Mineral properties}

\section{1 chemical multi element analysis}

The chemical multi-element analysis of a high copper gold concentrate sample is carried out, and the analysis results are shown in Table 1.
Table 1. chemical analysis results of main elements of a high copper gold concentrate $(/ \%)$

\begin{tabular}{ccccc}
\hline component & $\mathrm{Au}^{*}$ & $\mathrm{Ag}^{*}$ & $\mathrm{Cu}$ & $\mathrm{S}$ \\
content & 318.29 & 461.87 & 3.12 & 35.52 \\
\hline
\end{tabular}

*The unit is $\mathrm{g} / \mathrm{T}$.

It can be seen from table 1 that the grade of gold, silver, copperand sulfur in a high copper gold concentrate is high, in which copper, consume a lot of cyanide in the conventional cyanide leaching process, which has adverse effects on the conventional cyanide leaching.

\section{2 phase analysis}

\subsection{1 mineral composition of samples}

The main metal minerals in a high copper gold concentrate are galena and pyrite, followed by chalcopyrite, and a small amount of sphalerite, tetrahedrite, copper blue, blue chalcocite and other minerals. The relative contents of metal minerals in the samples are shown in Table 2.

Table 2. mineral composition and relative content of samples

\begin{tabular}{cc}
\hline Mineral name & content, $\%$ \\
Pyrite & 32.17 \\
Galena & 38.34 \\
Chalcopyrite & 17.74 \\
Sphalerite & 4.46 \\
Tetrahedrite & 0.96 \\
Other minerals & 6.33 \\
total & 100.00 \\
\hline
\end{tabular}




\subsection{2 distribution characteristics of gold minerals in samples}

The gold minerals in the samples are mainly native gold, followed by argent gold. Most of the native gold and silver gold deposits exist in the form of monomers, a small amount in the form of associated with pyrite and galena, and occasionally in the form of inclusions. It can be seen from table 3 that most of the gold in the sample is embedded in the form of monomer gold, accounting for $96.05 \%$ of the total gold in the sample; A small amount is lianshengti gold, and its gold share is $2.49 \%$; There is also a small amount of inclusion gold, accounting for $1.46 \%$ of the total gold.

Table 3. distribution characteristics of gold minera

\begin{tabular}{|c|c|c|c|}
\hline \multirow[t]{2}{*}{$\begin{array}{l}\text { Distribution } \\
\text { characteristics }\end{array}$} & $\begin{array}{l}\text { Mineral } \\
\text { name }\end{array}$ & $\begin{array}{l}\text { Relative } \\
\text { proportion } \\
\text { of gold } \\
\text { deposits, \% de }\end{array}$ & $\begin{array}{l}\text { Share of } \\
\text { gold in } \\
\text { gold } \\
\text { eposits, \% }\end{array}$ \\
\hline & Natural gold & 48.37 & 53.61 \\
\hline \multirow[t]{3}{*}{ Monomer gold } & $\begin{array}{l}\text { Silver gold } \\
\text { deposit }\end{array}$ & 47.51 & 42.44 \\
\hline & Total & 95.88 & 96.05 \\
\hline & Natural gold & 1.19 & 1.24 \\
\hline \multirow[t]{3}{*}{$\begin{array}{l}\text { Lianshengti } \\
\text { gold }\end{array}$} & $\begin{array}{l}\text { Silver gold } \\
\text { deposit }\end{array}$ & 1.35 & 1.25 \\
\hline & Total & 2.54 & 2.49 \\
\hline & Natural gold & 0.45 & 0.47 \\
\hline \multirow[t]{2}{*}{ Inclusion gold } & $\begin{array}{l}\text { Silver gold } \\
\text { deposit }\end{array}$ & 1.13 & 0.99 \\
\hline & Total & 1.58 & 1.46 \\
\hline
\end{tabular}

\section{Experimental study}

In order to improve the research efficiency, firstly, the dosage of copper salt, ammonia and thiosulfate was determined through the reagent dosage condition test, then the gold leaching index of thiosulfate was directly used in the test, and then the possibility of further improvement of gold leaching index was explored combined with pretreatment.

\section{1 reagent dosage condition test}

The main reagents used in the thiosulfate leaching process under the copper ammonia catalytic system are copper salt, ammonia water and thiosulfate, so the dosage of these three reagents is mainly investigated in the test of reagent dosage conditions. Other test conditions can be determined by consulting data. The $\mathrm{pH}$ control range of thiosulfate leaching is $8-11$. In order to control accurately, the $\mathrm{pH}$ is set at 9-10. If the stirring intensity is too high, it will increase the dissolved oxygen of pulp and promote the decomposition of thiosulfate, which is not conducive to leaching. Therefore, it is enough to ensure that there is no sink, and the stirring intensity is set at $400 \mathrm{R} / \mathrm{min}$. The leaching rate is faster with lower pulp concentration, and the liquid-solid ratio is $5: 1$. The temperature range of thiosulfate leaching is generally set between $40{ }^{\circ} \mathrm{C}$ and $80{ }^{\circ} \mathrm{C}$. The higher the temperature is, the faster the leaching rate is. However, considering the higher heating cost, the temperature is set at $40{ }^{\circ} \mathrm{C}$. The gold grade of high copper concentrate is high, and due to the low reaction temperature, the leaching time should be appropriately extended (about $5 \mathrm{~h}$ for conventional leaching), and the leaching time should be set at $8 \mathrm{~h}$.

\subsection{1 copper ion concentration test}

Copper ion is an important oxidant and catalyst. Firstly, the condition test of copper ion concentration was carried out to determine the optimal copper ion concentration. The specific test conditions are shown in Table 4.

Table 4. test conditions of copper ion concentration

\begin{tabular}{|c|c|c|c|c|}
\hline $\begin{array}{c}\text { Test } \\
\text { serial } \\
\text { number }\end{array}$ & $\begin{array}{l}\text { Copper ion } \\
\text { concentrati } \\
\text { on, } \mathrm{mol} / \mathrm{L}\end{array}$ & $\begin{array}{l}\text { Ammonia } \\
\text { concentrat } \\
\text { on, mol/L }\end{array}$ & $\begin{array}{l}\text { Thiosulfate } \\
\text { concentrati } \\
\text { on, mol/L }\end{array}$ & $\begin{array}{l}\text { Reaction } \\
\text { temperature } \\
,{ }^{\circ} \mathrm{C}\end{array}$ \\
\hline 1 & 0.04 & \multirow{5}{*}{1.5} & \multirow{5}{*}{0.3} & \multirow{5}{*}{40} \\
\hline 2 & 0.08 & & & \\
\hline 3 & 0.12 & & & \\
\hline 4 & 0.16 & & & \\
\hline 5 & 0.2 & & & \\
\hline $\begin{array}{c}\text { Test } \\
\text { serial } \\
\text { number }\end{array}$ & $\mathrm{pH}$ & $\begin{array}{c}\text { Stirring } \\
\text { intensity, } \\
\text { rpm }\end{array}$ & $\begin{array}{c}\text { Liquid } \\
\text { solid ratio }\end{array}$ & $\begin{array}{l}\text { Leaching } \\
\text { time, h }\end{array}$ \\
\hline $\begin{array}{l}1 \\
2\end{array}$ & \multirow{3}{*}{$9 \sim 10$} & \multirow{3}{*}{400} & \multirow{3}{*}{ 5:01 } & \multirow{3}{*}{8} \\
\hline $\begin{array}{l}3 \\
4\end{array}$ & & & & \\
\hline 5 & & & & \\
\hline
\end{tabular}

Table 5.test results of copper ion concentration

\begin{tabular}{cccc}
\hline $\begin{array}{c}\text { Test serial } \\
\text { number }\end{array}$ & $\begin{array}{c}\text { Copper ion Gold grade } \\
\text { concentrati of leaching } \\
\text { on, mol/L residue, g/t }\end{array}$ & $\begin{array}{c}\text { Gold leaching } \\
\text { rate, \% }\end{array}$ \\
\hline 1 & 0.04 & 299.32 & 5.96 \\
2 & 0.08 & 280.57 & 11.85 \\
3 & 0.12 & 273.06 & 14.21 \\
4 & 0.16 & 277.29 & 12.88 \\
5 & 0.20 & 282.61 & 11.21 \\
\hline
\end{tabular}

It can be seen from table 5 that when the copper ion concentration is $0.12 \mathrm{~mol} / \mathrm{L}$, the gold leaching rate reaches the maximum value of $14.21 \%$. The concentration of copper ion was determined as $0.12 \mathrm{~mol} / \mathrm{L}$ 


\subsection{2 ammonia concentration test}

Ammonia forms copper ammonia complex with copper ion, which affects the oxidation ability of copper ion and the consumption of thiosulfate. The concentration of copper ion was set at $0.12 \mathrm{~mol} / \mathrm{L}$, and the concentration of ammonia was changed. The specific test conditions are shown in Table 6.

Table 6. ammonia concentration test conditions

\begin{tabular}{|c|c|c|c|c|}
\hline $\begin{array}{c}\text { Test } \\
\text { serial } \\
\text { number }\end{array}$ & $\begin{array}{l}\text { Ammonia } \\
\text { concentrat } \\
\text { on, mol/L }\end{array}$ & $\begin{array}{l}\text { Copper ion } \\
\text { concentrat } \\
\text { on, mol/L }\end{array}$ & $\begin{array}{l}\text { Thiosulfate } \\
\text { concentrati } \\
\text { on, mol/L }\end{array}$ & $\begin{array}{l}\text { reaction } \\
\text { temperatu } \\
\text { re, }{ }^{\circ} \mathrm{C}\end{array}$ \\
\hline 1 & 0.5 & \multirow{5}{*}{0.12} & \multirow{5}{*}{0.3} & \multirow{5}{*}{40} \\
\hline 2 & 1 & & & \\
\hline 3 & 1.5 & & & \\
\hline 4 & 2 & & & \\
\hline 5 & 2.5 & & & \\
\hline $\begin{array}{c}\text { Test } \\
\text { serial } \\
\text { number }\end{array}$ & $\mathrm{pH}$ & $\begin{array}{l}\text { Stirring } \\
\text { intensity, } \\
\text { rpm }\end{array}$ & $\begin{array}{l}\text { Liquid } \\
\text { solid ratio }\end{array}$ & $\begin{array}{l}\text { Leaching } \\
\text { time, } \mathrm{h}\end{array}$ \\
\hline $\begin{array}{l}1 \\
2\end{array}$ & \multirow{3}{*}{$9 \sim 10$} & \multirow{3}{*}{400} & \multirow{3}{*}{$5: 1$} & \multirow{3}{*}{8} \\
\hline $\begin{array}{l}3 \\
4\end{array}$ & & & & \\
\hline 5 & & & & \\
\hline
\end{tabular}

Table 7. ammonia concentration test results

\begin{tabular}{cccc}
\hline $\begin{array}{c}\text { Test serial } \\
\text { number }\end{array}$ & $\begin{array}{c}\text { Ammonia } \\
\text { concentration } \\
\text { mol/L }\end{array}$ & $\begin{array}{c}\text { Gold grade of } \\
\text { leaching } \\
\text { residue, g/t }\end{array}$ & $\begin{array}{c}\text { Gold leaching } \\
\text { rate, \% }\end{array}$ \\
\hline 1 & 0.50 & 282.13 & 11.36 \\
2 & 1.00 & 268.04 & 15.79 \\
3 & 1.50 & 273.06 & 14.21 \\
4 & 2.00 & 276.32 & 13.19 \\
5 & 2.50 & 278.20 & 12.60 \\
\hline
\end{tabular}

It can be seen from table 7 that when the ammonia concentration is $1.0 \mathrm{~mol} / \mathrm{L}$, the gold leaching rate reaches the maximum value of $15.79 \%$. The concentration of ammonia was $1.0 \mathrm{~mol} / \mathrm{L}$.

\subsection{3 thiosulfate concentration test}

The thiosulfate ion of thiosulfate forms a complex with gold to realize gold leaching. The large consumption of thiosulfate is the main obstacle to its industrial application, so it is necessary to carry out the test of thiosulfate concentration conditions to determine the optimal concentration of thiosulfate. The concentrations of copper ion and ammonia were set at $0.12 \mathrm{~mol} / \mathrm{L}$ and $1.0 \mathrm{~mol} / \mathrm{L}$ respectively to change the concentration of thiosulfate. The specific test conditions are shown in Table 8.

Table 8. test conditions of thiosulfate concentration

\begin{tabular}{|c|c|c|c|c|}
\hline $\begin{array}{c}\text { Test } \\
\text { serial } \\
\text { number }\end{array}$ & $\begin{array}{l}\text { Thiosulfate } \\
\text { concentrati } \\
\text { on, mol/L }\end{array}$ & $\begin{array}{c}\text { Copper ion } \\
\text { concentration, } \\
\mathrm{mol} / \mathrm{L}\end{array}$ & $\begin{array}{l}\text { Ammonia } \\
\text { concentrat } \\
\text { on, mol/L }\end{array}$ & $\begin{array}{l}\text { reaction } \\
\text { i tempera } \\
\text { ture, }{ }^{\circ} \mathrm{C}\end{array}$ \\
\hline 1 & 0.10 & \multirow{5}{*}{0.12} & \multirow{5}{*}{1} & \multirow{5}{*}{40} \\
\hline 2 & 0.20 & & & \\
\hline 3 & 0.3 & & & \\
\hline 4 & 0.4 & & & \\
\hline 5 & 0.5 & & & \\
\hline $\begin{array}{c}\text { Test } \\
\text { serial } \\
\text { number }\end{array}$ & $\mathrm{pH}$ & $\begin{array}{l}\text { Stirring } \\
\text { intensity, rpm }\end{array}$ & $\begin{array}{c}\text { Liquid } \\
\text { solid ratio }\end{array}$ & $\begin{array}{c}\text { Leachin } \\
\text { g time, } \\
\mathrm{h}\end{array}$ \\
\hline 1 & \multirow{5}{*}{$9 \sim 10$} & \multirow{5}{*}{400} & \multirow{5}{*}{ 5:01 } & \multirow{5}{*}{8} \\
\hline 2 & & & & \\
\hline 3 & & & & \\
\hline 4 & & & & \\
\hline 5 & & & & \\
\hline
\end{tabular}

Table 9.test results of thiosulfate concentration

\begin{tabular}{cccc}
\hline $\begin{array}{c}\text { Test serial } \\
\text { number }\end{array}$ & $\begin{array}{c}\text { Thiosulfate } \\
\text { concentratio } \\
\text { n, mol/L }\end{array}$ & $\begin{array}{c}\text { Gold grade } \\
\text { of leaching } \\
\text { residue, g/t }\end{array}$ & $\begin{array}{c}\text { Gold } \\
\text { leaching } \\
\text { rate, \% }\end{array}$ \\
\hline 1 & 0.10 & 287.15 & 9.78 \\
2 & 0.20 & 260.48 & 18.16 \\
3 & 0.30 & 268.04 & 15.79 \\
4 & 0.40 & 272.02 & 14.54 \\
5 & 0.50 & 273.50 & 14.07 \\
\hline
\end{tabular}

It can be seen from table 9 that when the thiosulfate concentration is $0.2 \mathrm{~mol} / \mathrm{L}$, the gold leaching rate reaches the maximum of $18.16 \%$. The concentration of thiosulfate was $0.2 \mathrm{~mol} / 1$.

\section{2 multi stage thiosulfate leaching test}

The multi-stage leaching test of high copper ore was carried out, that is, the leaching residue from the previous stage was used as the raw material for the next stage. For gold, silver, copper and other high-grade ores, higher concentration of thiosulfate and ammonia should be selected. Referring to relevant data ${ }^{[4-5]}$, the test conditions are determined as follows: copper ion concentration $0.15 \mathrm{~mol} / \mathrm{L}$, thiosulfate concentration 0.3 $\mathrm{mol} / \mathrm{L}$, ammonia concentration $1.5 \mathrm{~mol} / \mathrm{L}$, temperature $40{ }^{\circ} \mathrm{C}, \mathrm{pH} 9-10$, liquid-solid ratio 5:1, stirring speed 400 $\mathrm{rpm}$, leaching time $40 \mathrm{~h}$. The results of multi-stage leaching test are shown in table 10. 
Table 10. multi stage thiosulfate leaching test results

\begin{tabular}{ccc}
\hline $\begin{array}{c}\text { Leaching } \\
\text { time, h }\end{array}$ & $\begin{array}{c}\text { Gold grade of leaching } \\
\text { residue, g/t }\end{array}$ & $\begin{array}{c}\text { Gold leaching } \\
\text { rate, \% }\end{array}$ \\
8 & 273.06 & 14.21 \\
16 & 262.24 & 17.61 \\
24 & 253.52 & 20.35 \\
32 & 248.93 & 21.79 \\
40 & 245.18 & 22.97 \\
\hline
\end{tabular}

After five stage leaching, the cumulative leaching rate of gold reached $22.97 \%$. With the increase of leaching time, the gold leaching rate increased slightly, but the leaching index was still very poor. The preliminary analysis shows that the existence of a large number of copper minerals has a negative impact on the gold leaching efficiency of high copper gold concentrate ${ }^{[6]}$. In the next step, the pretreatment method is considered to reduce the impact of copper minerals, and the possibility of further improving the gold leaching rate of high copper gold concentrate is investigated.

\section{3 pretreatment thiosulfate leaching test}

The high copper gold concentrate was pretreated with ammonia, sodium hydroxide and glycine respectively. The pretreated high copper gold concentrate was filtered, washed and dried, and then thiosulfate leaching test was carried out. The test conditions were as follows: copper ion concentration $0.15 \mathrm{~mol} / \mathrm{L}$, thiosulfate concentration $0.3 \mathrm{~mol} \mathrm{/} \mathrm{L,} \mathrm{ammonia} \mathrm{concentration} 1.5 \mathrm{~mol} / \mathrm{L}$, temperature $40{ }^{\circ} \mathrm{C}, \mathrm{pH}$ 9-10, liquid-solid ratio 5:1, stirring speed $400 \mathrm{rpm}$, leaching time $8 \mathrm{~h}$. The test results are shown in Table 11.

Table 11. pretreatment thiosulfate leaching test results

\begin{tabular}{cccc}
\hline $\begin{array}{c}\text { Test serial } \\
\text { number }\end{array}$ & $\begin{array}{c}\text { Pretreatment } \\
\text { mode }\end{array}$ & $\begin{array}{c}\text { Gold grade of } \\
\text { leaching } \\
\text { residue, g/t }\end{array}$ & $\begin{array}{c}\text { Gold } \\
\text { leaching } \\
\text { rate, \% }\end{array}$ \\
\hline 1 & $\begin{array}{c}\text { Ammonia } \\
\text { leaching } \\
\text { Alkali } \\
\text { leaching } \\
\text { Glycine }\end{array}$ & 261.94 & 17.70 \\
3 & pretreatment & 53.03 & 72.15 \\
\hline
\end{tabular}

The experimental results show that glycine pre leaching can obtain better gold leaching index than ammonia leaching and alkali leaching. The next step is to extend the leaching time, that is, to use the multi-stage leaching method to investigate the possibility of further improving the gold leaching rate.

\section{4 pretreatment multi stage thiosulfate leaching test}

In order to investigate whether prolonging the leaching time can further improve the leaching rate of gold, the leaching test of "alkali leaching, glycine pretreatment multi-stage thiosulfate leaching process" was carried out for high copper concentrate. After pretreatment, multi-stage thiosulfate leaching was carried out for high copper concentrate. The leaching residue from the previous stage was used as the raw material for the next stage after washing, and the leaching solution used each time was clean water. The experimental conditions are: copper ion concentration $0.15 \mathrm{~mol} / \mathrm{L}$, thiosulfate concentration $0.3 \mathrm{~mol} / \mathrm{L}$, ammonia concentration 1.5 mol / L, temperature $40{ }^{\circ} \mathrm{C}, \mathrm{pH}$ 9-10, liquid-solid ratio 5:1, stirring speed $400 \mathrm{rpm}$, leaching time $32 \mathrm{H}$. The test results are shown in Table 12.

Table 12. pretreatment multi stage thiosulfate leaching test results

\begin{tabular}{cccc}
\hline $\begin{array}{c}\text { Pretreatment } \\
\text { mode }\end{array}$ & $\begin{array}{c}\text { Leaching } \\
\text { time, } \mathrm{h}\end{array}$ & $\begin{array}{c}\text { Gold grade of } \\
\text { leaching } \\
\text { residue, g/t }\end{array}$ & $\begin{array}{c}\text { Gold leaching } \\
\text { rate, \% }\end{array}$ \\
\hline & 8 & 88.64 & 72.15 \\
Alkali & 16 & 52.61 & 83.47 \\
leaching & 24 & 38.18 & 88 \\
& 32 & 35.25 & 88.93 \\
& 40 & 31.4 & 90.13 \\
Glycine & 8 & 53.03 & 83.34 \\
pretreatment & 24 & 17.15 & 94.61 \\
& 32 & 11.38 & 96.42 \\
& 40 & 10.26 & 96.78 \\
\hline
\end{tabular}

The results show that the gold leaching rate of the high copper gold concentrate pretreated by glycine reaches $96.96 \%$ after $40 \mathrm{~h}$ leaching, which is close to the effect of sodium cyanide leaching.

\section{4 conclusion}

A high copper gold concentrate is leached by direct thiosulfate process, and the gold leaching rate is low. After the pretreatment of glycine leaching, the gold leaching rate reached $96.96 \%$, which was close to the cyanide leaching index of the production site. However, the cost of this process is much higher than that of conventional cyanidation leaching process due to the variety, large consumption and high price of chemicals used in pretreatment and thiosulfate leaching. Therefore, the environmental and economic benefits should be considered comprehensively to decide whether to apply the new non cyanide leaching process.

\section{References}

1.Shen Zhihui et al. Experimental study on thiosulfate leaching of a micro disseminated gold deposit in Guizhou [J]. Mining and metallurgical engineering, 2013, 05:85-90 
2.Zhong Jin et al., present situation and development of thiosulfate leaching of gold $[\mathrm{J}]$. Mining and metallurgy, 2014, 04:65-69

3.Lei Li. Experimental study on leaching gold from a refractory copper bearing gold ore by thiosulfate method [J]. Gold, 2012, 10:40-43

4.Zhao Hefei et al. Research status of influence factors on thiosulfate leaching of gold [J]. Gold science and technology, 2018, 1:105-114

5.Liu $\mathrm{Lu}$ et al. Experimental study on recovery and utilization of gold tailings by cyanide free process [J]. Comprehensive utilization of mineral resources, 2019, 02:109-111

6.Huang huaiguo, gold extraction from a foreign copper bearing gold mine by ammoniacal cyanide method [J]. Comprehensive utilization of mineral resources, 2014, 05:50-54 